American Journal of Agricultural and Biological Sciences 6 (3): 433-439, 2011

ISSN 1557-4989

(C) 2011 Science Publications

\title{
Computing Evaporanspiraton from Weather Data Obtained from Distant, Non-Reference Weather Stations in a Hyper-Arid Region
}

\author{
ElNesr Mohammad Nabil and Alazba Abdurrahman Ali \\ College of Agriculture and Food Sciences, King Saud University, Riyadh, Saudi Arabia
}

\begin{abstract}
Problem statement: Reference agro-climatic Weather Stations (WS) are rarely found in newly reclaimed areas. The usage of weather data from non-reference WS may lead to inaccurate estimations of Evapo Transpiration (ET), especially if the non-reference stations are distant from the reclaimed location. Approach: Weather data from four WS located at Riyadh were used to calculate ET by using Penman Monteith (PM) and Hargreaves equations. PM equation was applied with both alfalfa and grass reference crops. Calculations were done with and without temperature correction for non-reference weather stations. All calculations were compared with measured lysimeter data and corrections in Hargreaves formula were suggested. Results: (1): Weather data from non-reference WS can be used safely to calculate ET only when temperature corrections are applied. (2) Hargreaves formula underestimates ET at all locations in the study area. By applying the simple linear correction to the data, highly acceptable results are obtainned. (3) The ET ratio between alfalfa and grass in Riyadh is 1.25. Conclusion: The study concluded that temperature correction for non-reference WS is essential to ensure acceptable ET calculations. Usage of Hargreaves formula is recommended with the corrections suggested in the study due to its simplicity.
\end{abstract}

Key words: Penman monteith, hargreaves formula, weather stations, data correction, hyper arid, evapo transpiration, non-reference, equation's parameters, reference crop, weather stations

\section{INTRODUCTION}

Determining the Evapo Transpiration (ET) is the base of many disciplines including the irrigation system design, irrigation scheduling and hydrologic and drainage studies (Irmak and Haman, 2003). Perfect determination of ET is a big challenge for investigators especially in arid and hyper-arid regions. Actual crop ET is computed by multiplying reference ET by the crop factor. Reference ET is the summation of evaporation and transpiration produced by a reference crop in specific growth conditions (height, coverage and health). ET value depends on two main factors, the selected reference crop and the climatic data (Allen, 1998).

The Kingdom of Saudi Arabia (KSA) is one of the most arid countries in the world and suffers persistent water shortage problems; however, more than $88 \%$ of water consumption in KSA is due to agricultural related activities (Faruqui et al., 2001). Hence, several researches were performed to assess the ET in KSA. Some estimated the reference ET (Al-Ghobari, 2000; ElNesr et al., 2010), some determined Crop coefficients others assessed the ET for specified crops (Al-Omran et al., 2004; Al-Amoud et al., 2010)
For open field agriculture, the reference ET has traditionally been predicted by using Either Grass $\left(\mathrm{ET}_{\mathrm{o}}\right)$ or alfalfa $\left(\mathrm{ET}_{\mathrm{r}}\right)$. Each of these two crops has some conditions to be considered as a reference crop (Wright et al., 2000). The selection of either crop as reference crop was studied by several investigators (Allen et al., 2000; Howell, 2000; Wright, 1996; Wright et al., 2000). It was recommended by the American Society of Civil Engineers Task Committee (ASCE-TC) to use a single equation for both reference crops, each with different constants (Allen, 2005). They recommended standardizing the equation with two surfaces, the short crop (about $0.12 \mathrm{~m}$ height e.g., theclipped cool season grass) and the tall crop (about $0.50 \mathrm{~m}$ height e.g., the full cover alfalfa). The heights of crop, however, may vary according to the crop variety and location's geography. When using crop with different height, one should clearly-mention the used height beside the ET data.

Climate data are acquired from Weather Stations (WS) whose location is an important consideration for the quality of the data. Reference WS have to be located inside a cropped area (normally with grass) in order to ensure the same environmental conditions for station's gauges as that of the cultivated crops. On the other hand, stations located in these reference conditions usually record less temperature than Non-

Corresponding Author: ElNesr Mohammad Nabil, College of Agriculture and Food Sciences, King Saud University Riyadh, Saudi Arabia, Mobile: 966544909445 
Reference (NR) weather stations (Allen, 1996). This was attributed to the cooling effect of the crop. Allen, (1996) suggested an adjustment for the recorded temperature in Non-Reference Weather Stations (NRWS) so that the resultant temperatures could be used to give the reference ETo.

In many locations, Reference WS (RWS) are not found especially for newly reclaimed desert areas. To perform preliminary studies for an area, one should use the nearest stations' data. This situation is probably affected by the distance between the field and the weather station. There are 13 districts in KSA and some of them are larger in size than many countries. Arriyadh District's area, for instance, is $380,000 \mathrm{~km}^{2}$ which is $17 \%$ of the country's area. The main weather stations in Arriyadh and other places in the kingdom are situated at airports. The current study aimed to know the possibility of using the weather data recorded at these stations instead of reference agro-climatic data. Hence, the aim of this study is to benchmark the ET calculation by using the RWS and the NRWS at Riyadh, Saudi Arabia in comparison to the reference evapotranspiration based on lysimeter readings in reference conditions.

Used formulas: The original Penman-Monteith equation (PM) for determining the evapotranspiration is expressed as follows (Allen, 1998):

$$
\mathrm{ET}=\frac{\Delta\left(\mathrm{R}_{\mathrm{n}}-\mathrm{G}\right)+\rho_{\mathrm{a}} \times \mathrm{c}_{\mathrm{p}} \times \frac{\left(\mathrm{e}_{\mathrm{s}}-\mathrm{e}_{\mathrm{a}}\right)}{\mathrm{r}_{\mathrm{a}}}}{\lambda\left(\Delta+\gamma\left(1+\frac{\mathrm{r}_{\mathrm{s}}}{\mathrm{r}_{\mathrm{a}}}\right)\right)}
$$

Where :

$$
\mathrm{ET}=\text { Evapotranspiration }\left[\mathrm{mm} \mathrm{day}^{-1}\right]
$$

$\Delta \quad=$ Slope of the vapor pressure curve $\left[\mathrm{kPa}^{\circ} \mathrm{C}^{-1}\right]$

$\mathrm{R}_{\mathrm{n}}=$ Net radiation at the crop surface $\left[\mathrm{MJ} \mathrm{m}^{-2}\right.$ day $\left.^{-1}\right]$

$\mathrm{G}=$ Soil heat flux density $\left[\mathrm{MJ} \mathrm{m}^{-2} \mathrm{day}^{-1}\right]$

$\rho \mathrm{a}=$ Mean air density at constant pressure $\left[\mathrm{kg} \mathrm{m}^{-3}\right]$

$\mathrm{Cp}=$ Specific heat at constant pressure $\left[\mathrm{MJ} \mathrm{kg}^{-1}{ }^{\circ} \mathrm{C}^{-1}\right]$

$\mathrm{e}_{\mathrm{s}}-\mathrm{e}_{\mathrm{a}}=$ Vapor pressure deficit $[\mathrm{kPa}]$

$\mathrm{e}_{\mathrm{s}}=$ Saturation vapor pressure $[\mathrm{kPa}]$

$\mathrm{e}_{\mathrm{a}}=$ Actual vapor pressure $[\mathrm{kPa}]$

$\mathrm{r}_{\mathrm{a}}=$ Aerodynamic resistance $\left[\mathrm{s} \mathrm{m}^{-1}\right]$

$\mathrm{r}_{\mathrm{s}} \quad=$ The bulk surface resistance $\left[\mathrm{s} \mathrm{m}^{-1}\right]$

$\lambda=$ Latent heat of vaporization $\left[\mathrm{MJ} \mathrm{kg}^{-1}\right]$

$\gamma \quad=$ The psychrometric constant $\left[\mathrm{kPa}^{\circ} \mathrm{C}^{-1}\right]$

The formulae of the equation's parameters are detailed by Allen, (1998) in chapters 2 and 3. The main component of ET calculation is the air Temperature (T). Although it does not appear explicitly in the equation but it is included in most of the equation's parameters (like $\Delta, \mathrm{R}_{\mathrm{n}}, \mathrm{c}_{\mathrm{p}}, \rho_{\mathrm{a}}, \mathrm{e}_{\mathrm{s}}, \mathrm{e}_{\mathrm{a}}, \lambda$ and $\gamma$ ). Hence, Allen (1996) concluded that correcting the temperature values of the NRWS to an adjusted value fixes the entire ET equation to give an acceptable value close to the RWS value. Allen's method can be summarized in the following steps.

Calculating the actual vapor pressure

$e_{a}: e_{a}=0.005\left(R_{x} e_{o}\left[T_{n}\right]+R_{n} e_{o}\left[T_{x}\right]\right)$

Where:

$\mathrm{T}_{\mathrm{n}}=$ Minimum dry bulb air temperature $\left[{ }^{\circ} \mathrm{C}\right]$

$\mathrm{T}_{\mathrm{x}}=$ Maximum dry bulb air temperature $\left[{ }^{\circ} \mathrm{C}\right]$

$\mathrm{RH}_{\mathrm{x}}=$ Maximum relative humidity [\%]

$\mathrm{RH}_{\mathrm{n}}=$ Minimum relative humidity [\%]

In the absence of $\mathrm{RH}_{\mathrm{x}}$ and $\mathrm{RH}_{\mathrm{n}}$ and the presence of the average relative humidity $\left(\mathrm{RH}_{\mathrm{a}}\right)$, one can use the equation $\mathrm{e}_{\mathrm{a}}=0.005 \mathrm{RH}_{\mathrm{a}}\left(\mathrm{e}_{\mathrm{o}}\left[\mathrm{T}_{\mathrm{n}}\right]+\mathrm{e}_{\mathrm{o}}\left[\mathrm{T}_{\mathrm{x}}\right]\right)$

Calculating the dew point temperature (if not measured), $T_{d}=\frac{116.91+237.3 \ln \left(e_{a}\right)}{16.78-\ln \left(e_{a}\right)}$

Computing the $\Delta \mathrm{T}=\mathrm{T}_{\mathrm{n}}-\mathrm{T}_{\mathrm{d}}, \quad\left(\mathrm{T}_{\mathrm{n}}\right.$ is the minimum temperature).

For arid and semi-arid environments, If $\Delta \mathrm{T}>2$ then adjusting the maximum temperature, $T_{x}$, where $T_{x}$ $($ corr $)=T_{x}-0.5(\Delta T-2),{ }^{\{\text {corr }\}}$ stands for 'corrected' value. Finally, doing the same for $T_{n}$ if $\Delta T \leq 2$, then no correction is needed.

For sites with limited weather data, Allen, (1998) suggested using a modified version of the Hargreaves equation (HG) as an alternative method for determining ET; they also suggested calibrating the HG equation, Eq. 2, through linear fit comparing to the trustful PM equation, Eq. 1.

$$
\begin{aligned}
& \mathrm{ET}_{\mathrm{HG}}=0.0023 \mathrm{R}_{\mathrm{a}}\left(\mathrm{T}_{\mathrm{a}}+17.8\right)\left(\mathrm{T}_{\mathrm{x}}-\mathrm{T}_{\mathrm{n}}\right)^{0.5} \\
& \mathrm{ET}_{\mathrm{PM}}=\mathrm{c}_{1}+\mathrm{c}_{2} \mathrm{ET}_{\mathrm{HG}}
\end{aligned}
$$

where, suffixes HG and PM stands for Hargreaves and Penman-Monteith, respectively; $c_{1}, \quad c_{2}$ : fitting parameters, $R_{a}$ : the extraterrestrial radiation, $\mathrm{MJ} \mathrm{m}^{-2} \mathrm{~h}^{-1}$ :

$\mathrm{R}_{\mathrm{a}}=37.6 \mathrm{~d}_{\mathrm{r}}\left(\omega_{\mathrm{s}} \sin \varphi \sin \delta+\sin \omega_{\mathrm{s}} \cos \varphi \cos \delta\right)$

Where:

$\mathrm{d}_{\mathrm{r}}$ :

Earth to Sun

$\left.\mathrm{d}_{\mathrm{r}}=1+0.033 \cos (0.0172 \mathrm{~J})\right\} ; \delta$ : $\quad=$ Solar declination

[rad] 
$\{\delta=0.409 \sin (0.0172 \mathrm{~J}-1.39)\} ; \varphi:$

= latitude $[\mathrm{rad}]$

$\omega_{\mathrm{s}}$

$[\mathrm{rad}]_{\omega_{\mathrm{s}}}=\arccos (-\tan \varphi \tan \delta)$

All these parameters depend on the Julian day number $(\mathrm{J})$ which is calculated by Craig (1984) formula, as follows:

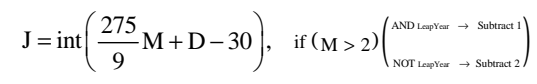

where, M: month of the year; $D$ : day of the month. Julian day ranges from 1 to 366 (in leap year).

Notice that the ET $_{\mathrm{HG}}$ resulted from Eq. 2 is measured in $\mathrm{MJ} \mathrm{m}^{-1} \mathrm{~h}^{-2}$, while the ET PM resulted from Eq. 3 is in $\mathrm{mm} \mathrm{d}^{-1}$

Data sources: We used two types of data in this study; first is the weather data, from which we calculated the ET value and the second is the field ET data. For weather data, two WS located at the educational farm of the King Saud University, naming Campbell and Davis, were selected as agro-climatic (reference) WS. On the other hand, Two WS at Old Riyadh airport and King Khaled airport (location shown in Fig. 1) were used as domestic (non-reference) WS.

Reference Field data was obtained from AlAmoud et al. (2010) based on five years project of ET evaluation through lysimeters in 9 zones throughout the country.

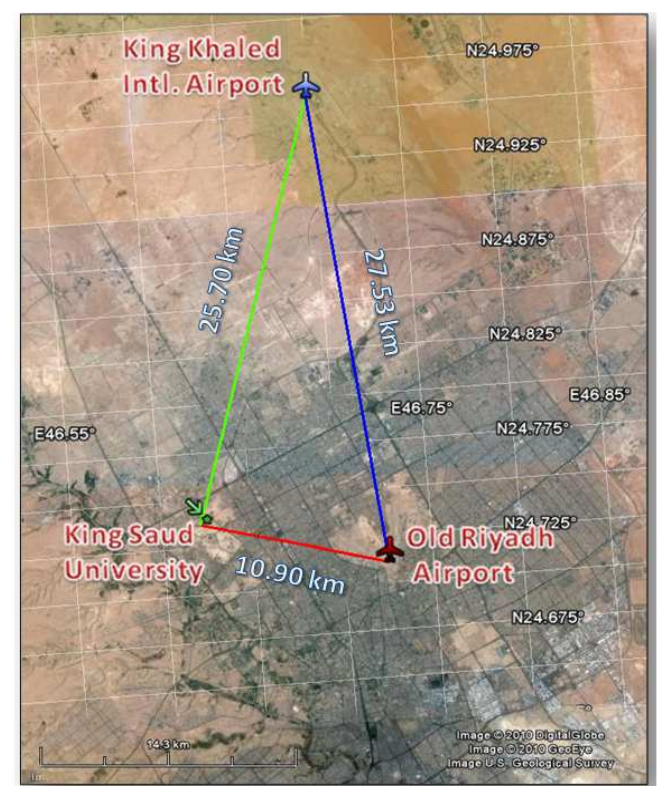

Fig. 1: Location and distances between the study locations
All of the weather data was recorded on daily bases while the field data was recorded on monthly bases. Hence, daily ET values for all the studied weather stations were calculated and later, the data was summarized as average monthly ET values. The recorded dataset varies from station to station. For airport's weather stations, complete records from 19852009 were obtained. For Campbell and Davis weather stations, the records were from 1993-2006. We limited our study to the least-size dataset i.e., Campbell's dataset for an appropriate comparison. The databases of the studied stations were not so coincident. For all stations, the commonly available data parameters include the dry bulb temperature (max., min. and avg.), relative humidity (max., min. and avg.), rainfall and wind speed (average). In addition to the common variables for airports stations, the wet bulb temperature (max., min. and avg.), the atmospheric pressure at sea level and at station level and the actual vapor pressure are also recorded. While for Campbell station, the actual vapor pressure and solar radiation are recorded. Finally, for Davis station, the only addition to common parameters is the solar radiation. This information is summarized in Table 1. Solar Radiation $\left(\mathrm{R}_{\mathrm{s}}\right)$ and vapor pressure $\left(e_{a}\right)$ are essential parameters for computing ET. If not recorded at the weather station, these parameters are calculated. Calculation procedures of these parameters are shown in the Appendix.

As mentioned above, the field data was obtained from Al-Amoud et al. (2010). The five years project used Alfalfa cultivated in weighing lysimeters located at Riyadh and at 8 more locations in the Kingdom. The daily and monthly values of irrigation, drainage, precipitation and water consumption are recorded by them, however, only the monthly results were published in the published quick guide.

\section{MATERIALS AND METHODS}

For each of the four stations mentioned in Table 1, weather data were manipulated as daily records. Using the raw data, we calculated $\mathrm{ET}_{\mathrm{PMg}}, \mathrm{ET}_{\mathrm{PMa}}$ and $\mathrm{ET}_{\mathrm{HG}}$; where the suffix PMg and PMa stands for Penman Monteith formula for $0.12 \mathrm{~m}$ grass reference crop and $0.25 \mathrm{~m}$ alfalfa reference crop, respectively.

The entire calculations were repeated after applying Allen (1996) corrections to the temperature data but only for non agro-climatic stations. To simplify data representation and discussion, we assigned symbols to data sources as shown in Table 2. Since the published data by Al-Amoud et al. (2010) were on monthly bases and since Allen (1998) suggested calibrating Hargreaves formula using monthly data, subsequently, we converted the daily calculated data to monthly bases. 
Am. J. Agri. \& Biol. Sci., 6 (3): 433-439, 2011

Table 1: Recorded parameters of the studied weather stations

\begin{tabular}{|c|c|c|c|c|c|c|c|c|c|}
\hline & $\begin{array}{l}\text { Temperature } \\
\text { (Dry bulb) }\end{array}$ & $\begin{array}{l}\text { Relative } \\
\text { (Wet bulb) }\end{array}$ & $\begin{array}{l}\text { Wind } \\
\text { Humidity }\end{array}$ & $\begin{array}{l}\text { Solar } \\
\text { speed }\end{array}$ & $\begin{array}{l}\text { Vapor } \\
\text { radiation }\end{array}$ & $\begin{array}{l}\text { Atm. pressure } \\
\text { pressure }\end{array}$ & $\begin{array}{l}\text { Commualative } \\
\text { sea level }\end{array}$ & Station level & Rainfall \\
\hline Campbell station & $\checkmark$ & . & $\checkmark$ & $\checkmark$ & $\checkmark$ & $\checkmark$ & 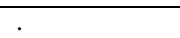 & 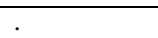 & $\checkmark$ \\
\hline Davis station & $\checkmark$ & & $\checkmark$ & $\checkmark$ & . & $\checkmark$ & & & $\checkmark$ \\
\hline Riyadh old airport & $\checkmark$ & $\checkmark$ & $\checkmark$ & $\checkmark$ & . & . & $\checkmark$ & $\checkmark$ & $\checkmark$ \\
\hline King khaled intl. airport & $\checkmark$ & $\checkmark$ & $\checkmark$ & $\checkmark$ & . & . & $\checkmark$ & $\checkmark$ & $\checkmark$ \\
\hline
\end{tabular}

Table 2: The used data sources in the study and their symbols

\begin{tabular}{|c|c|c|c|c|c|c|c|}
\hline \multirow{2}{*}{$\begin{array}{l}\text { Data is } \\
\text { Location }\end{array}$} & \multicolumn{3}{|l|}{ Measured } & \multicolumn{4}{|l|}{ Calculated } \\
\hline & \multicolumn{5}{|c|}{ Educational Farm, King Saud University } & \multicolumn{2}{|l|}{ Airport } \\
\hline Name & \multirow{2}{*}{$\begin{array}{l}\text { Project data } \\
0\end{array}$} & \multirow{2}{*}{\begin{tabular}{l} 
Campbell \\
\hdashline 1
\end{tabular}} & \multirow{2}{*}{$\begin{array}{l}\text { Davis } \\
------ \\
2\end{array}$} & \multicolumn{2}{|c|}{ Riyadh Old Airport } & \multicolumn{2}{|c|}{ King Khaled Intl. Airport } \\
\hline$\#$ & & & & 3 & 4 & 5 & 6 \\
\hline Reference data? & - & yes & yes & no & no & no & no \\
\hline Corrected data? & no need & no need & no need & yes & no & yes & no \\
\hline Symbols & $\operatorname{Px}(\mathrm{L})$ & $\mathrm{Cs}(\mathrm{a}, \mathrm{g}, \mathrm{H})$ & $\operatorname{Ds}(\mathrm{a}, \mathrm{g}, \mathrm{H})$ & $\mathrm{Oc}(\mathrm{a}, \mathrm{g}, \mathrm{H})$ & $\mathrm{On}(\mathrm{a}, \mathrm{g}, \mathrm{H})$ & $\mathrm{Kc}(\mathrm{a}, \mathrm{g}, \mathrm{H})$ & $\mathrm{Kn}(\mathrm{a}, \mathrm{g}, \mathrm{H})$ \\
\hline Longitude: $24 \mathrm{~N}$, & $44^{\prime} 12.24 "$ & $44^{\prime} 12.24^{\prime \prime}$ & $44^{\prime} 12.24^{\prime \prime}$ & $42^{\prime} 35.46^{\prime \prime}$ & $42^{\prime} 35.46^{\prime \prime}$ & $57 ’ 27.00 \prime$ & 57 '27.00" \\
\hline Latitude: $46 \mathrm{E}$, & $37^{\prime} 14.90 "$ & $37^{\prime} 14.90^{\prime \prime}$ & $37^{\prime} 14.90^{\prime \prime}$ & $43^{\prime} 30.54^{\prime \prime}$ & $43^{\prime} 30.54^{\prime \prime}$ & $41 ' 55.54 "$ & 41'55.54"' \\
\hline
\end{tabular}

Symbols: A: Alfalfa; C: Corrected; C: Campbell; D: Davis; g: Grass; H: Hargreaves; K: King Khalid airport; L: Lysimeters; n: Normal; O: Old airport; P: Project data; s: Reference; $x$ : Experimental

\section{RESULTS}

The ET data for the six datasets are presented graphically in Fig. 2. The charts are denoted by letters ' $a$ ' to ' $\mathrm{f}$ ' for Campbell reference WS, Davis reference WS, old Riyadh airport corrected dataset, old Riyadh airport raw dataset, King Khalid airport corrected dataset and King Khalid airport raw dataset, respectively. Four ET values for each dataset i.e., measured ET, $\{\mathrm{Px}(\mathrm{L})\} ;$ grass based $\mathrm{PM}$ evapotranspiration $\{\mathrm{g}\}$; alfalfa based $\mathrm{PM}$ evapotranspiration $\{a\}$; and Hargreaves method ET were plotted.

All of the calculated data groups were compared with the measured dataset and the correlation coefficient for each data group pair was calculated. The correlation coefficients are illustrated in Fig. (3).

Next, the conversion parameters, mentioned in Eq. 3, between HG and PM formulas were calculated, these values are shown in Table 3. Finally, the ET ratio between alfalfa and grass was calculated and compared to the value of 1.15 which was reported by Pruitt and Doorenbos and Pruitt (1977).The evaluated values for different sites are listed in Table 4.

\section{DISCUSSION}

Campbell and Davis weather stations are located at the educational farm of the King Saud University; the lysimeters' experiment of Al-Amoud et al. (2010) was held at the same location. Figure $2 \mathrm{a}$ and $\mathrm{b}$ shows the results of measured and calculated ET by the three mentioned methods. Both stations show underestimation of Hargreaves formula and overestimation of PM alfalfa, 'a', calculations. It is strange that the grass ET, 'g', almost coincides with the measured alfalfa data. This may be attributed to some lack of precision either in the field measurements devices or to some calibration errors of the weather stations. The data at old airport (Fig. 2c and d) behaves differently and the closer values to the measured alfalfa ET are the calculated alfalfa values, especially at months 1-3 and 9-12. The situation is different for King Khalid airport's station (Fig 2e and f) as the raw data appear to give fuzzy trend dissimilar to the measured data, Fig. 2f. After applying the data correction, the shape of the curve improved dramatically, Fig. 2e. This is confirmed in Fig. 3, which shows the Correlation Coefficient (CC) between measured data versus each data group. Although all the values of cc are more than 0.9 , which is a very good value, however, the ' $\mathrm{Kn}$ ' dataset is the worst representation of actual state. On the other hand, it strangely appears that the corrected values of King Khalid's airport $(\mathrm{K})$ are the top most accurate representatives of the measured data. This is probably due to the geographic condition of the ' $\mathrm{K}$ ' airport, which is outside of the city and almost surrounded with desert lands, in addition to the long distance between the Educational Farm stations (EF) and the ' $\mathrm{K}$ ' airport (about $25.7 \mathrm{~km}$ ), as shown in Fig. 1. The Old airport $(\mathrm{O})$ is near $(10.9 \mathrm{~km})$, in fact almost in the middle of the city and surrounded by buildings, roads and some green areas. The correction of the ' $\mathrm{O}$ ' data improves the ' $\mathrm{g}$ ' and ' $\mathrm{a}$ ' data groups, while it worsens the ' $H$ ' data group, as shown in Fig. 3. 


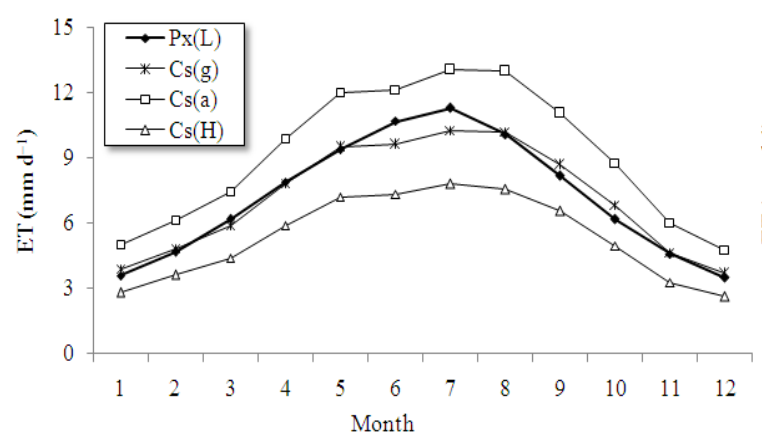

(a)

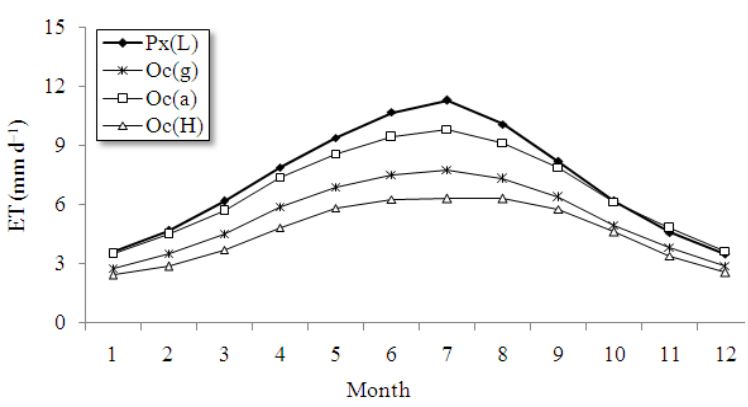

(c)

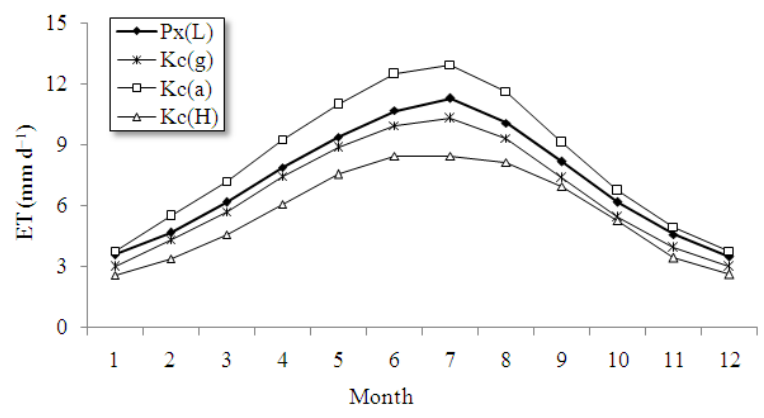

(e)

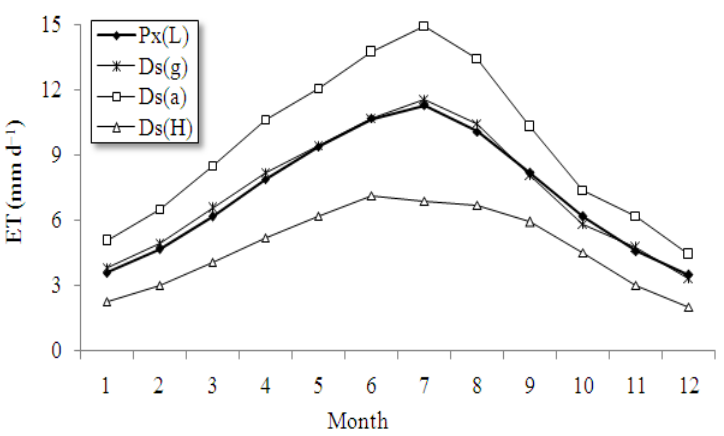

(b)

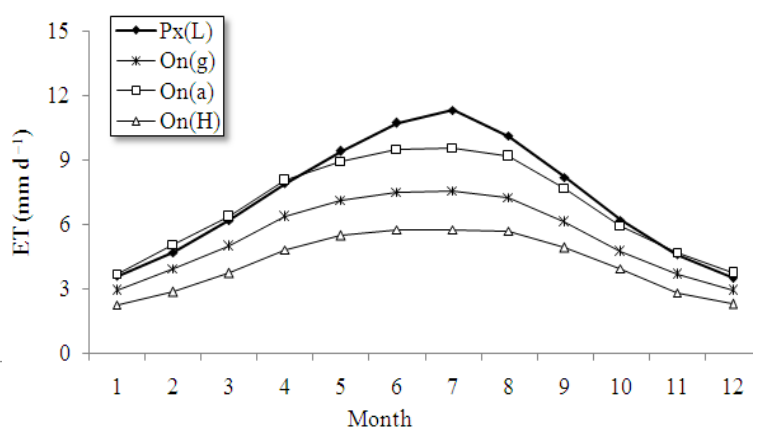

(d)

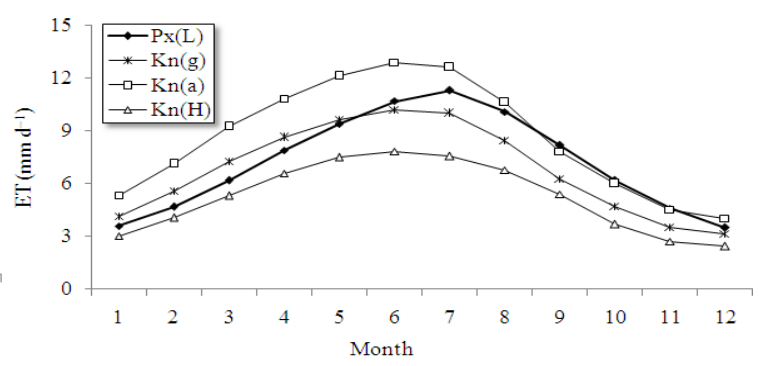

(f)

Fig. 2: Monthly evapotranspiration of the studied region, showing three datasets in each chart compared to measuredevapotranspiration, where: a: Alfalfa; c: Corrected; C: Campbell; D: Davis; g: Grass; H: Hargreaves; K: King Khalid airport; L: Lysimeters; n: Normal; O: Old airport; P: Project data; s: Reference; x: Experimental

Table 3: Fitting equations to fit hargreaves ET formula to PM formula

\begin{tabular}{|c|c|c|c|c|}
\hline & Grass & & Alfalfa & \multirow[b]{2}{*}{$r^{2}$} \\
\hline & Equation & $r^{2}$ & Equation & \\
\hline $\mathrm{Cs}$ & $\mathrm{PMg}=1.280 \mathrm{HG}+0.324$ & 0.9983 & $\mathrm{PMa}=1.608 \mathrm{HG}+0.526$ & 0.9985 \\
\hline Ds & $\mathrm{PMg}=1.563 \mathrm{HG}-0.122$ & 0.9591 & $\mathrm{PMa}=1.993 \mathrm{HG}-0.046$ & 0.9746 \\
\hline $\mathrm{Kc}$ & $\mathrm{PMg}=1.189 \mathrm{HG}-0.140$ & 0.9792 & $\mathrm{PMa}=1.481 \mathrm{HG}-0.140$ & 0.9874 \\
\hline $\mathrm{Kn}$ & $\mathrm{PMg}=1.296 \mathrm{HG}+0.013$ & 0.9857 & $\mathrm{PMa}=1.619 \mathrm{HG}+0.109$ & 0.9912 \\
\hline Oc & $\mathrm{PMg}=1.214 \mathrm{HG}-0.211$ & 0.9812 & $\mathrm{PMa}=1.517 \mathrm{HG}-0.243$ & 0.9879 \\
\hline On & $\mathrm{PMg}=1.298 \mathrm{HG}-0.021$ & 0.9908 & $\mathrm{PMa}=1.624 \mathrm{HG}+0.055$ & 0.9940 \\
\hline
\end{tabular}

From the same figure, it can be concluded that the PM calculations improves dramatically after applying the
Allen (1996) correcting algorithm to the data, while for HG formula, applying the corrections improves the accuracy for ' $\mathrm{K}$ ' station but worsens it for ' $\mathrm{O}$ ' station. In general, Hargreaves equation gives very satisfactory results of ET for Riyadh city and the equation can be used trustfully especially in the absence of some climatic factors like wind speed and radiation. However, we applied the linear correction equations and found some excellent fitted equations, as listed in Table 3. All the equations are excellently fitted with minimum value of coefficient of determination $\left(\mathrm{r}^{2}\right)$ of 0.974 . 


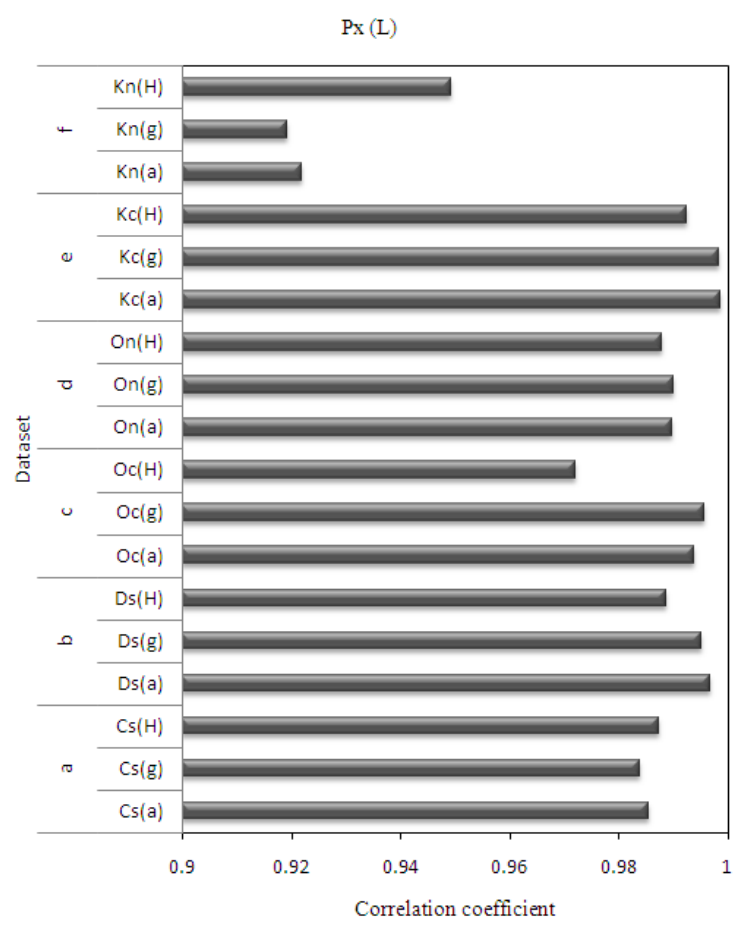

Fig. 3: The correlation coefficient between the measured data and the calculated data for all data groups in the six datasets

Table 4: Actual ration between alfalfa and grass ET for the study area

\begin{tabular}{lllllll}
\hline & $\mathrm{Cs}$ & $\mathrm{Ds}$ & $\mathrm{Kc}$ & $\mathrm{Kn}$ & $\mathrm{Oc}$ & $\mathrm{On}$ \\
\hline Slope & 1.2553 & 1.2691 & 1.2428 & 1.2470 & 1.2458 & 1.2493 \\
Intercept & 0.1250 & 0.1576 & 0.0533 & 0.1070 & 0.0399 & 0.0919 \\
$\mathrm{r}^{2}$ & 0.9998 & 0.9995 & 0.9997 & 0.9998 & 0.9996 & 0.9998 \\
\hline
\end{tabular}

It can be approximated that $\mathrm{PM}_{\mathrm{g}}=1.30 \times \mathrm{HG}-0.05$ for grass reference, while $\mathrm{PM}_{\mathrm{a}}=1.64 \times \mathrm{HG}+0.1$ for alfalfa reference. For more accurate values each station should be calibrated, as shown in Table 3.

The ratio between alfalfa ET and grass ET $\left(\mathrm{ET}_{\text {alfalfa }} / \mathrm{ET}_{\text {grass }}\right.$, or $\left.\mathrm{ET}_{\mathrm{r}} / \mathrm{ET}_{\mathrm{o}}\right)$ is always taken as 1.15 for arid regions, as recommended by Pruitt and Doorenbos and Pruitt, (1977). This value was used in many researches (Al-Ghobari, 2000) when studying the Saudi Arabia ET, We evaluated this value for each of the studied data groups and a linear relationship between $\mathrm{ET}_{\text {alfalfa }}$ and $\mathrm{ET}_{\text {grass }}$ is obtained, as shown in Table 4. The slope of ETr/ETo is almost 1.25 for all stations and using less value may result in some bias in data.

\section{CONCLUSION}

Due to the easiness of finding non-reference agroclimatic WS than the agro-climatic ones in the newly reclaimed areas, their weather data had to be corrected through simple procedure. Two reference and two nonreference WS were taken in Riyadh city and corrections were applied to non-reference WS only. We calculated the evapotranspiration using Penman Monteith and Hargreaves formulas. PM was calculated for two reference crops i.e., alfalfa and grass. Calculated data were compared with measured data. Results show an admirable enhancement in data accuracy after applying the data correction to the non-reference stations. The simple ET formula of Hargreaves underestimates the actual ET. The situation changes after applying the simple linear fitting equation to the resulted values. The ratio between alfalfa and grass ET was found to be 1.25 for Riyadh area. It is concluded to use the temperature correction method when using non-reference stations. Hargreaves formula is recommended to be used after applying the suggested fit in this study, especially when the wind speed and radiation data are missing.

\section{ACKNOWLEDGEMENT}

The researchers wish to express their deep thanks and gratitude to "Shaikh Mohammad Bin Husain Alamoudi" for his kind financial support to the King Saud University, http://www.ksu.edu.sa, through the research chair "Shaikh Mohammad Alamoudi Chair for Water Researches" (AWC), http://awc.ksu.edu.sa, where this study is part of the AWC chair activities in the "Projects and Research" axis. Thanks should also be expressed to the Presidency of Meteorology and Environment in Riyadh, KSA, who kindly provided the meteorological data.

\section{REFERENCES}

Faruqui, N.I., A.K. Biswas and M.J. Bino, 2001. Water Management in Islam. 1st Edn., United Nations University Press, Tokyo, ISBN: 9280810367, pp: 149.

Al-Ghobari, H.M., 2000. Estimation of reference evapotranspiration for southern region of Saudi Arabia. Irrig. Sci., 19: 81-86. DOI: 10.1007/s002710050004

Al-Amoud, A., Al-Takhis, A., Awad, F., Al AbdelKader and A., Al-Mushelih, 2010. A guide for Evaluating Crop Water Requirements in the Kingdom of Saudi Arabia. King Abdulaziz City for Science and Technology, Abdulaziz, pp: 104.

Allen, R.G., 1996. Assessing integrity of weather data for reference evapotranspiration estimation. J. Irrig. Drainage Eng., 122: 97-106. DOI: 10.1061/(ASCE)0733-437(1996)122:2(97) 
Allen, R.G., 1998. Crop Evapotranspiration: Guidelines for computing crop water requirements. $1^{\text {st }}$ Edn., Food and Agriculture Organization of the United Nations, Rome, ISBN: 9251042195, pp: 300.

Allen, R. G., I. A. Walter, R. Elliott, B. Mecham and M. E. Jensen, 2000. Issues, requirements and challenges in selecting and specifying a standardized et equation. CMIS.

Allen, R.G., 2005. The ASCE standardized reference evapotranspiration equation. 1st Edn., ASCE Publications, Reston, ISBN: 078440805X, pp: 216.

Al-Omran, A.M., F.S. Mohammed, H.M. Al-Ghobari and A.A. Alazba, 2004. Determination of evapotranspiration of tomato and squash using lysimeters in central Saudi Arabia. Intl. Agric. Engr. J., 13: 27-36.

ElNesr, M., Alazba A. and M. Abu-Zreig, 2010. Analysis of Evapotranspiration Variability and Trends in the Arabian Peninsula. Am. J. of Environ. $\quad$ Sci., 6: 535-547. DOI:10.3844/ajessp.2010.535.547

Irmak, S. and D.Z. Haman, 2003. Evapotranspiration: Potential or Reference? University of Florida.
Howell, T.A., S.R. Evett, A.D. Schneider, D.A. Dusek and K.S. Copeland, 2000. "Irrigated fescue grass ET compared with calculated reference grass ET." Proceedings of the Decennial Symposium, Nov. 14-16, American Society of Agricultural Engineers, Phoenix, AZ. pp: 228- $\square 42$.

Doorenbos, J. and W. Pruitt, 1977. Guidelines for Predicting Crop Water Requirements. $1^{\text {st }}$ Edn., Food and Agriculture Organization of the United Nations, Rome, ISBN: 9251002797, pp: 144.

Wright, J.L., 1996. Derivation of Alfalfa and Grass Reference Evapotranspiration. In: Evapotranspiration and Irrigation Scheduling, Camp, C.R. and E.J. Sadler (Eds). American Society of Agricultural Engineers, St. Joseph, Mich., ISBN: 0929355822, pp: 133-140.

Wright, J.L., R.G. Allen and T.A. Howell, 2000. Conversion between evapotranspiration references and methods. Proceedings of the 4th Decennial Symposium, NWISRL Publisher, USAAZ-Phoenix, pp; 251-259. 